\title{
Inhibition of Microbial Cell Wall Synthesis by Lipopeptin A
}

\author{
Masahiro NishII, Kiyoshi Isono* and Kazuo IZAKI ${ }^{\dagger}$ \\ The Institute of Physical and Chemical Research, Wako-shi, \\ Saitama 351, Japan. \\ ${ }^{\dagger}$ Department of Agricultural Chemistry, Tohoku University, \\ Sendai 980, Japan
}

Received September 3, 1980

\begin{abstract}
Lipopeptin A is a selective inhibitor of in vitro peptidogiycan synthesis of $E$. coli $Y-10$. In the study here it inhibited the formation of lipid intermediates from UDP-[U- $\left.{ }^{14} \mathrm{C}\right] \mathrm{GlcNAc}$ and UDPMurNAc-L-Ala-D-Glu-meso-DAP-D-Ala-D-Ala, but did not inhibit the formation of MurNAc-

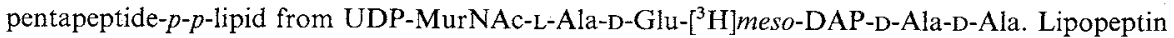
$A$ also did not have a significant effect on polymerase reaction. Therefore, the inhibition of the formation of GlcNAc-MurNAc-pentapeptide- $p$ - $p$-lipid from MurNAc-pentapeptide- $p$-p-lipid and UDP-GlcNAc is concluded to be the site of action.

Lipopeptin A inhibits fungal growth, causing swelling in mycelia. It did not significantly inhibit the incorporations of ${ }^{14} \mathrm{C}$-labeled glucosamine, thymidine, uridine, phenylalanine, and sodium acetate into TCA insoluble fraction of mycelial suspension of Piricularia oryzae. In in vitro test, however, it inhibited the transfer of mannose from GDP-[U- $\left.{ }^{14} \mathrm{C}\right]$ mannose $\left(\mathrm{ID}_{50}=250 \mu \mathrm{g} / \mathrm{ml}\right)$ and GlcNAc from UDP-[U $\left.{ }^{14} \mathrm{C}\right] \mathrm{GlcNAc}\left(\mathrm{ID}_{50}=100 \mu \mathrm{g} / \mathrm{ml}\right)$ into proteoheteroglycan with a particulate enzyme of Piricularia oryzae. It also slightly inhibited chitin synthesis $\left(\mathrm{ID}_{50}=750 \mu \mathrm{g} / \mathrm{ml}\right)$ in the same enzyme system, but did not inhibit $\beta-1,3$-glucan synthesis.
\end{abstract}

In the screening for inhibitors of bacterial peptidoglycan synthesis, lipopeptin A was isolated from the culture filtrates and mycelia of Streptomyces sp. No. AC-69, which resembles Streptomyces violaceochromogenes. ${ }^{1}$

Lipopeptin A is a member of peptolide antibiotics having a fatty acid side chain. The structure is shown in Fig. 1. The determination of the structure is reported in a separate paper. ${ }^{2)}$ Amphomycin ${ }^{3)}$ and enduracidin ${ }^{4} 6$ ) belonging to this group of antibiotics inhibit peptidoglycan synthesis and the site of action was reported to be the inhibition of the formation of lipid intermediates. ${ }^{7,8)}$

Lipopeptin A inhibits in vitro peptidoglycan synthesis of Escherichia coli Y-10 but shows only weak inhibitory activity against bacterial cells. On the other hand, it shows inhibitory activity against some species of phytopathogenic fungi inducing characteristic swelling of mycelia. ${ }^{\text {1) }}$

This paper describes the site of action of lipopeptin $\mathrm{A}$ in peptidoglycan synthesis of $E$. coli. In vitro studies on cell wall glycan synthesis of Piricularia oryzae is also described.

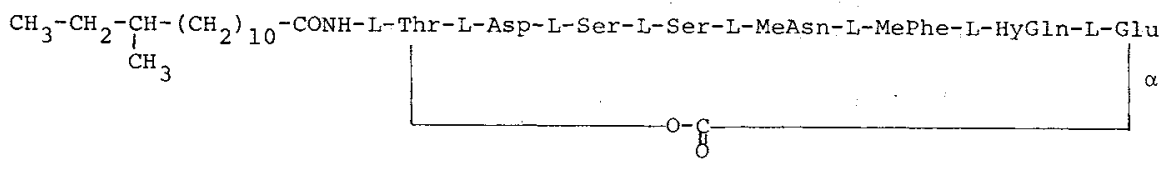

$$
\begin{array}{ll}
\text { MeAsn } & \text { N-methylasparagine } \\
\text { MePhe } & \text { N-methylphenylalanine } \\
\text { HyGln } & \text { threo- } B \text {-Hydroxyglutamine }
\end{array}
$$

* Address correspondence to this author.

FIG. 1. Structure of Lipopeptin A. 


\section{MATERIALS AND METHODS}

Radiochemicals. UDP-[U $\left.-{ }^{14} \mathrm{C}\right] \mathrm{GlcNAc}, \quad$ UDP-[U$\left.{ }^{14} \mathrm{C}\right] \mathrm{glucose}$, GDP-[U- $\left.{ }^{14} \mathrm{C}\right]$ mannose, [U- $\left.{ }^{14} \mathrm{C}\right]$ uridine, [2$\left.{ }^{14} \mathrm{C}\right]$ thymidine, $\quad \mathrm{D}-\left[1-{ }^{14} \mathrm{C}\right]$ glucosamine, and $\mathrm{L}$-[U${ }^{14} \mathrm{Clphenylalanine}$ were purchased from Radiochemical Centre, Amersham/Searle. $\left[2-{ }^{14} \mathrm{C}\right]$ Sodium acetate was purchased from New England Nuclear Corporation. UDP-MurNAc- $\left(\left[{ }^{3} H\right] D A P\right)$-pentapeptide was prepared as previously described. ${ }^{91}$

Organisms and growth conditions. Bacillus cereus $\mathrm{T}$ and Escherichia coli Y-10 were grown in botillon medium (peptone $1 \%$, meat extract $0.3 \%, \mathrm{NaCl} 0.5 \%$, Eiken Chemical Co.) at $37^{\circ} \mathrm{C}$ on a rotary shaker. Piricularia oryzae was grown in Y.G. liquid medium (yeast extract $0.4 \%$, glucose $2 \%$ at $27^{\circ} \mathrm{C}$ on a rotary shaker.

In order to obtain UDP-MurNAc-pentapeptide, $B$. cereus $\mathrm{T}$ was grown in a 30 liter jar fermentor containing 15 liters of bouillon medium.

Preparation of particulate enzyme of E. coli $Y-10$. Particulate enzyme was prepared by grinding cells of $E$. coli $\mathrm{Y}-10$ with sea sand $(200 \sim 400$ mesh) according to the procedure previously reported. ${ }^{91}$

Preparation of UDP-MurNAC-1-Ala-D-Glu-meso-DAPD-Ala-D-Ala. UDP-MurNAc-pentapeptide was obtained after inducing its accumulation in cells of $B$. cereus $T$ by treatment with $12.5 \mu \mathrm{g}$ of vancomycin per ml according to the procedure previously reported. ${ }^{97}$ From 15 liters of the culture, approximately 500 O.D. unit $\left(A_{260}\right)$ of UDPMurNAc-pentapeptide was isolated.

Peptidoglycan synthesis and lipid intermediate formation from $U D P-\left[U_{-}{ }^{14} C\right] G l c N A C$ and $U D P-M u r N A C-$ pentapeptide. A typical incubation mixture contains $5 \mu \mathrm{mol}$ of Tris- $\mathrm{HCl}$ buffer $(\mathrm{pH} 7.5), 1 \mu \mathrm{mol}$ of $\mathrm{MgCl}_{2}$, $0.033 \mu \mathrm{mol}$ of UDP-[U-14 C]-GleNAc (Sp.Act. $300 \mu \mathrm{mol}$, $13000 \mathrm{cpm}), 10 \mu \mathrm{mol}$ of UDP-MurNAc-pentapeptide, and $5 \mu \mathrm{l}$ of the particulate enzyme in a final volume of $50 \mu \mathrm{l}$ was incubated at $37^{\circ} \mathrm{C}$ for $10 \sim 120 \mathrm{~min}$. After incubation, the reaction mixture was heated in a steam bath for $1 \mathrm{~min}$ and then spotted on Whatman $3 \mathrm{MM}$ paper. After descending paper chromatography with isobutyric acid- $1 \mathrm{~N} \mathrm{NH}_{4} \mathrm{OH}$ (5:3) for $16 \mathrm{hr}$, spots on the paper corresponding to peptidoglycan $(R f 0)$ and lipid intermediate $(R f 0.9)$ were cut out and radioactivity was measured using toluene scientilation cocktail by a Packard Tricarb model 3330 liquid scintillation counter.

Formation of MurNAc-pentapeptide-p-p-lipid. The lipid intermediate was prepared by the method described by Tanaka et $a l^{7)}$ A reaction mixture $(50 \mu l)$ containing $2 \times 10^{-4} \mathrm{M}$ UDP-MurNAc-L-Ala-D-Glu- $\left.{ }^{3} \mathrm{H}\right]$-meso-DAPD-Ala-D-Ala (Sp. Act. $17.6 \mu \mathrm{Ci} / \mu \mathrm{mol}, 12000 \mathrm{cpm}), 0.1 \mathrm{~m}$ Tris-HCl buffer ( $\mathrm{pH} 7.5), 20 \mathrm{mM} \mathrm{MgCl}_{2}$ and $5 \mu \mathrm{l}$ of the particulate enzyme was incubated for $10 \sim 30 \mathrm{~min}$. After incubation, the lipid intermediate was extracted with $150 \mu$ of $n$-butanol- $6 \mathrm{M}$ pyridinium acetate, $\mathrm{pH} 4.2(2: 1)$. The extracts were transferred into a scintillation vial and evaporated to dryness. The radioactivity was measured using dioxane scintillation cocktail.

Isolation of GicNAc-MurNAc-pentapeptide-p-p-lipid and its utilization for polymerase reaction. The lipid intermediate was isolated by the method described by Anderson $e t a l^{10}$

For polymerase reaction, $0.1 \mathrm{ml}$ of the extract of the lipid intermediate was dried under nitrogen stream and other components of the reaction mixture; $0.1 \mathrm{M}$ Tris- $\mathrm{HCl}$ buffer (pH 7.5), $200 \mu \mathrm{M} \mathrm{MgCl}_{2}$, and $10 \mu \mathrm{l}$ of the particulate enzyme were added to it to give the final volume of $100 \mu \mathrm{l}$. After incubation for $2 \mathrm{hr}$ at $37^{\circ} \mathrm{C}$, the reaction mixture was heated for I min and spotted on Whatman 3 MM paper. After descending paper chromatography with isobutyric acid-1 $\mathrm{N} \mathrm{NH}_{4} \mathrm{OH}(5: 3)$ for $16 \mathrm{hr}$, radioactivity at the origin was measured.

Chitin synthesis. A reaction mixture contained $16.7 \mathrm{~mm}$ Tris-maleate- $\mathrm{NaOH}$ buffer pH $7.2,0.6 \mathrm{~mm}$ UDP-[U$\left.{ }^{14} \mathrm{C}\right] \mathrm{GlcNAc}$ (Sp. Act. $300 \mu \mathrm{Ci} / \mu \mathrm{mol}, 13000 \mathrm{cpm}$ ), $2.7 \mathrm{~mm}$ $\mathrm{MgCl}_{2}, 0.6 \mathrm{mM} \quad \beta$-mercaptoethanol, $0.06 \mathrm{~mm}$ EDTA, $17 \mathrm{~mm} \mathrm{GlcNAc}$, and $10 \mu \mathrm{l}$ of the particulate enzyme of $P$. oryzae, prepared according to the procedure of Hori et $a l .{ }^{11}$ in a total volume of $60 \mu \mathrm{l}$. Incubation was carried out for $2 \mathrm{hr}$ at $25^{\circ} \mathrm{C}$ and the reaction was terminated by heating in a boiling water bath for $1 \mathrm{~min}$. The reaction mixture was spotted on Whatman 3 MM paper and paper chromatography was performed overnight in isobutyric acid- $1 \mathrm{~N} \mathrm{NH}_{4} \mathrm{OH}(5: 3)$. Radioactivity at the origin was cut out and measured using toluene scintillator.

B-1,3-Glucan synthesis. $\beta-1,3-G l u c a n$ synthesis was measured according to the procedure developed recently in our laboratory. ${ }^{(2)}$

A reaction mixture containing $3.41 \times 10^{-3} \mathrm{M}$ UDP-[U${ }^{14} \mathrm{CJ}$-glucose (Sp. Act. $239 \mu \mathrm{Ci} / \mu \mathrm{mol}, 15000 \mathrm{cpm}$ ), $20 \mathrm{~mm}$ sodium cacodylate- $\mathrm{HCl}$ buffer $\mathrm{pH}$ 6.2, $0.6 \mathrm{~mm}$ cellobiose, $2.4 \mathrm{mM} \mathrm{MgCl}_{2}$, and $10 \mu \mathrm{l}$ of $P$. oryzae particulate enzyme in a total volume of $50 \mu \mathrm{l}$ was incubated at $25^{\circ} \mathrm{C}$ for $1 \mathrm{hr}$. After incubation, the reaction mixture was boiled for 2 min and then spotted on Whatman $3 \mathrm{MM}$ paper. After descending paper chromatography by ethanol $-1 \mathrm{~N}$ acetic acid $(7: 3)$ overnight, radioactivity at the origin was measured.

Incorporation of ${ }^{14} \mathrm{C}$-mannose and ${ }^{14} \mathrm{C}-\mathrm{GlcNAc}$ into proteoheteroglycan. A reaction mixture containing $1.4 \times 10^{-3} \mathrm{~mm} \quad$ GDP-[U- $\left.{ }^{14} \mathrm{C}\right]$-mannose (Sp.Act. $\quad 146$ $\mu \mathrm{Ci} / \mu \mathrm{mol})$ or $6.7 \times 10^{-4} \mathrm{~mm}$ UDP-[U- $\left.{ }^{14} \mathrm{C}\right]-\mathrm{GlcNAC}$ (Sp,Act. $300 \mu \mathrm{Ci} / \mu \mathrm{mol}$ ), $20 \mathrm{~mm}$ sodium cacodylate- $\mathrm{HCl}$ buffer $\mathrm{pH} 6.5,10 \mathrm{~mm} \mathrm{MnCl}_{2}, 1 \mathrm{~mm} \beta$-mercaptoethanol, and $10 \mu \mathrm{l}$ of $P$. oryzae particulate enzyme in a total volume 
of $50 \mu \mathrm{l}$ was incuvated at $25^{\circ} \mathrm{C}$ for $30 \mathrm{~min}$. After incubation, reaction was terminated by adding $100 \mu 1$ of chloroform-methanol $(2: 1)$ and spotted on Whatman 3 MM paper. After descending paper chromatography with isobutyric acid-1 $\mathrm{N} \mathrm{NH}_{4} \mathrm{OH}(5: 3)$ overnight, radioactivity at the origin was measured.

\section{RESULTS}

\section{Effect of Lipopeptin $A$ on peptidoglycan} synthesis

By a particulate enzyme system of $E$. coli $\mathrm{Y}$ 10 , peptidoglycan is synthesized from UDPMurNAc-pentapeptide and UDP-GlcNAc via two lipid intermediates, e.g., MurNAcpentapeptide- $p$ - $p$-lipid and GlcNAc-MurNAcpentapeptide- $p$ - $p$-lipid. Effect of lipopeptin A on lipid intermediates and peptidoglycan syntheses was examined with this system.

The time courses of syntheses of lipid intermediate and peptidoglycan from UDP$\left[\mathrm{U}-{ }^{14} \mathrm{C}\right] \mathrm{GlcNAc}$ and UDP-MurNAcpentapeptide are shown in Fig. 2. Lipopeptin A inhibited both syntheses completely at the concentration of $500 \mu \mathrm{g} / \mathrm{ml}$. At $150 \mu \mathrm{g} / \mathrm{ml}$ of lipopeptin A, both syntheses were inhibited by $50 \%$, as calculated from the initial reaction velocity (Fig. 3). This finding suggests that the inhibition of peptidoglycan synthesis is caused by the inhibition of lipid intermediate formation. Two steps are known in the formation of lipid intermediates. The first is the formation of MurNAc-pentapeptide- $p$ - $p$-lipid and the second is the formation of GlcNAcMurNac-pentapeptide- $p$ - $p$-lipid from the former and UDP-GlcNAc. If UDP-GlcNAc is omitted from the reaction mixture, only the first step should proceed without the second step. As clearly shown in Fig. 4, lipopeptin A did not inhibit the formation of the first lipid intermediate, MurNAc-pentapeptide- $p$ - $p$-lipid from UDP-MurNAc-([3 H]DAP)-pentapeptide. We also tested the effect of lipopeptin $A$ on polymarase reaction using crude GlcNAc-MurNAc-pentapeptide- $p$ - $p$-lipid obtained according to the procedure of Anderson et al. ${ }^{10)}$

Inhibition of peptidoglycan synthesis by

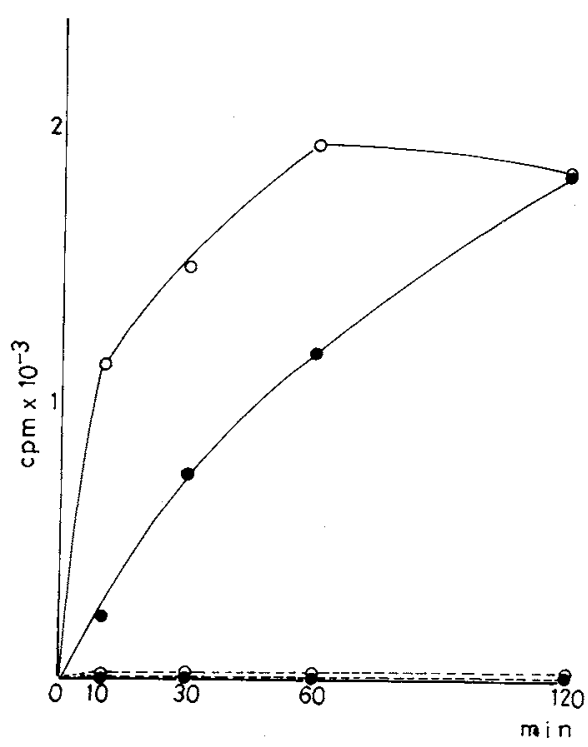

FIG. 2. Effect of Lipopeptin A on Lipid Intermediate and Peptidoglycan Syntheses.

A reaction mixture containing $0.33 \mu \mathrm{M}$ of UDP-[U$\left.{ }^{14} \mathrm{C}\right] \mathrm{GlcNAc}$ (Sp. Act. $300 \mu \mathrm{Ci} / \mu \mathrm{mol}$ ), $50 \mu \mathrm{m}$ of Tris- $\mathrm{HCl}$ buffer $\mathrm{pH} 7.5,10 \mu \mathrm{M}$ of $\mathrm{MgCl}_{2}, 100 \mu \mathrm{M}$ of UDPMurNAc-pentapeptide, and $50 \mu \mathrm{l}$ of $E$. coli Y-10 particulate enzyme in a total volume of $500 \mu \mathrm{l}$ was incubated at $37^{\circ} \mathrm{C}$. Periodically, $50 \mu$ aliquots were taken up, inactivated, and subjected to paper chromatography using isobutyric acid- $1 \mathrm{~N} \mathrm{NH} \mathrm{NH}_{4} \mathrm{OH}(5: 3)$, which separated peptidoglycan (origin) and lipid intermediate $(R f$ $0.9)$. Radioactivity was measured in a liquid scintillation counter.

$\bigcirc$, lipid intermediate; - , no antibiotic; $\bullet$, peptidoglycan; ---, lipopeptin A, $500 \mu \mathrm{g} / \mathrm{ml}$.

lipopeptin A from this lipid intermediate was found to be very weak, if there was any at all. In the same conditions, vancomycin, a selective inhibitor of this polymerase reaction, showed almost complete inhibition at the concentration of $125 \mu \mathrm{g} / \mathrm{ml}$ (Table I).

These results indicate that lipopeptin A inhibits selectively $\mathrm{N}$-acetylglucosamine transferase, which catalyzes the formation of GlcNAc-MurNAc-pentapeptide- $p$ - $p$-lipid from MurNAc-pentapeptide- $p$ - $p$-lipid and UDP-GlcNAc.

\section{Effect on fungal cell wall synthesis}

Lipopeptin A infibits growth of P. oryzae at the concentration of $150 \mu \mathrm{g} / \mathrm{ml}^{1)}$ and the 


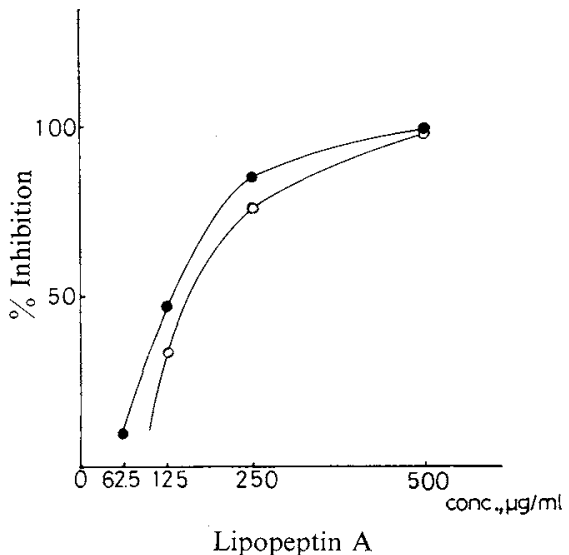

FIG. 3. Inhibition of Lipid Intermediate and Peptidoglycan Syntheses by Lipopeptin A.

The reaction mixture is the same as that shown in Fig. 2. $\bigcirc$, lipid intermediate $\left(37^{\circ} \mathrm{C}, 10 \mathrm{~min}\right) ;-$, peptidoglycan $\left(37^{\circ} \mathrm{C}, 30 \mathrm{~min}\right)$.

Initial reaction velocity was measured from the radioactivities of peptidoglycan or lipid intermediate formed in $30 \mathrm{~min}$ and $10 \mathrm{~min}$ respectively, in the absence or presence of various concentrations of lipopeptin A. Percent inhibition $=$ (radioactivity incorporated in the absence of lipopeptin A - radioactivity incorporated in the presence of lipopeptin $\mathrm{A} / \mathrm{radioactivity} \mathrm{incorporated}$ in the absence of lipopeptin A) $\times 100$.

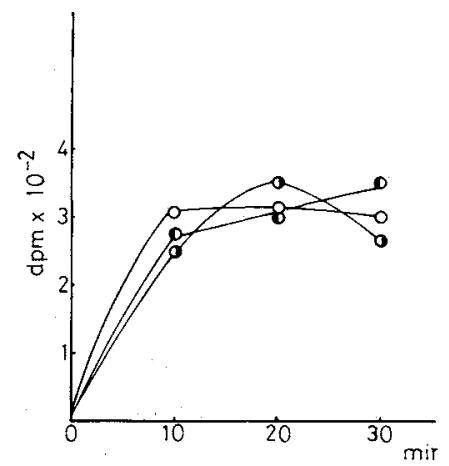

FIG. 4. Effect of Lipopeptin A on the Formation of MurNAc-pentapeptide- $p$ - $p$-lipid.

A reaction mixture contained $2 \times 10^{-4} \mathrm{M}$ UDPMurNAc-L-Ala-D-Glu- $\left[{ }^{3} \mathrm{H}\right]-m e s o-D A P-D-A l a-D-A l a$ (Sp.Act. $176 \mu \mathrm{Ci} / \mu \mathrm{mol}, 12000 \mathrm{dpm}$ ), $0.1 \mathrm{M}$ Tris $-\mathrm{HCl}$ buffer $\mathrm{pH} 7.5,0.02 \mathrm{M} \mathrm{MgCl}_{2}$, and $5 \mu \mathrm{l}$ of $E$. coli $\mathrm{Y}-10$ particulate enzyme in a total volume of $50 \mu \mathrm{l}$. After incubation at $37^{\circ} \mathrm{C}$ for the time indicated, lipid intermediate was extracted with $150 \mu \mathrm{l}$ of $n$-butanol-6m pyridinium acetate $\mathrm{pH} 4.2(2: 1)$ and transferred in a scintillation vial, evaporated and radioactivity was measured.

O, no antibiotic; $\boldsymbol{D}$, lipopeptin A $500 \mu \mathrm{g} / \mathrm{ml} ; \mathbf{O}$, lipopeptin A $125 \mu \mathrm{g} / \mathrm{ml}$.
Table I. The Effect of Lipopeptin

A AND VANCOMYCIN ON

POLYMerase REACtion

Each reaction mixture contained crude [U${ }^{14}$ C]GlcNAc-MurNAc-pentapeptide- $p$ - $p$-lipid $\quad(18000$ cpm), $0.1 \mathrm{M}$ Tris- $\mathrm{HCl}$ buffer $\mathrm{pH} 7.5,200 \mu \mathrm{M} \mathrm{MgCl}_{2}$, antibiotic as indicated, and $10 \mu \mathrm{l}$ of $E$. coli Y-10 particulate enzyme in a total volume of $100 \mathrm{ul}$. Incubation was conducted for $2 \mathrm{hr}$ at $37^{\circ} \mathrm{C}$

\begin{tabular}{lcc}
\hline \multicolumn{1}{c}{ Antibiotic added } & $\begin{array}{c}\text { Radioactivity at } \\
\text { the origin } \\
\text { (cpm) }\end{array}$ & $\%$ Inhibition \\
\hline None & 99 & \\
Lipopeptin A $500 \mu \mathrm{g} / \mathrm{ml}$ & 46 & 53 \\
Lipopeptin A $125 \mu \mathrm{g} / \mathrm{ml}$ & 116 & 0 \\
Vancomycin $125 \mu \mathrm{g} / \mathrm{ml}$ & 18 & 82 \\
\hline
\end{tabular}

swelling of mycelia was observed at little below this concentration.

This indicates that the mechanism of action of this antibiotic is related to the inhibition of cell wall biosynthesis. For example, selective inhibitors of chitin synthetase, polyoxins caused swelling of mycelia and spores of phytopathogenic fungi. ${ }^{13)}$ Therefore, we tested the effect of lipopeptin A on incorporation of glucosamine, a component of fungal cell wall, into TCA insoluble fraction of mycelial suspension of Piricularia oryzae. As shown in Fig. 5, lipopeptin A inhibited the incorporation of $\mathrm{D}-\left[1-{ }^{14} \mathrm{C}\right]$ glucosamine only slightly at the concentration of $1 \mathrm{mg} /$ ml. Incorporation of other radiochemicals, e.g., $\left[\mathrm{U}-{ }^{14} \mathrm{C}\right]$ uridine, $\quad\left[2^{14} \mathrm{C}\right]$ thymidine, $\quad \mathrm{L}$-[U$\left.{ }^{14} \mathrm{C}\right]$ phenylalanine, and $\left[2-{ }^{14} \mathrm{C}\right]$ sodium acetate were also not significantly inhibited (data not shown).

Next, we tested the effect of lipopeptin A on in vitro synthesis of cell wall components of $P$. oryzae using a particulate enzyme system. Nakajima et al. ${ }^{13 \sim 15)}$ reported that the cell wall of $P$. oryzae constitutes of at least three different polysaccharides; proteo-heteroglycan containing D-mannose, D-galactose, $\beta$-1,3glucan, and chitin. Of the cell wall components, $\beta$-1,3-glucan occupies more than $60 \%$, while the contents of heteroglycan and chitin are $10 \%$ and $13 \%$ respectively. 


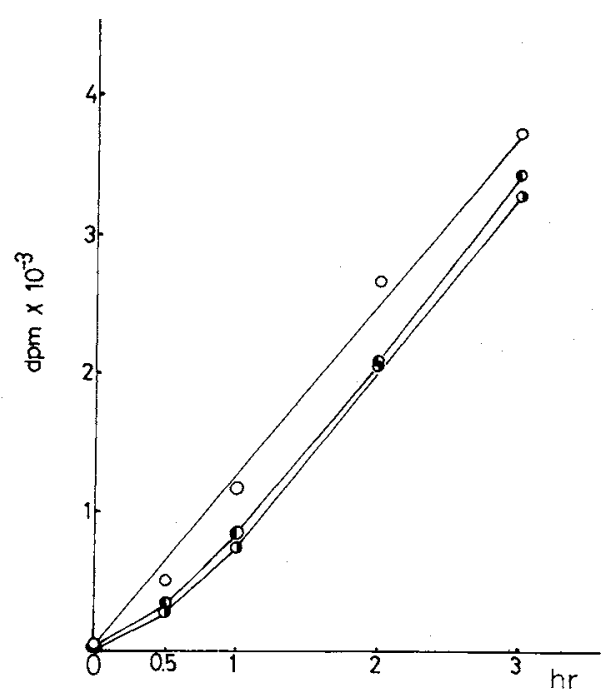

FiG. 5. Effect of Lipopeptin A on the Incorporation of Glucosamine into TCA Insoluble Fraction of Piricularia oryzae.

At $30 \mathrm{~min}$ incubation after the addition of lipopeptin $\mathrm{A}$ into the mycerial suspension, $\mathrm{D}-\left[1-{ }^{14} \mathrm{C}\right]$ glucosamine 0.1 $\mu \mathrm{Ci}(5.88 \mu \mathrm{Ci} / \mu \mathrm{mol})$ was added and the incubation was started.

O, no antibiotic; $D$, lipopeptin A $1 \mathrm{mg} / \mathrm{ml} ;$ lipopeptin A $100 \mu \mathrm{g} / \mathrm{ml}$.

Lipopeptin A inhibited $\beta$-1,3-glucan synthesis only by $17 \%$ at the concentration of $1 \mathrm{mg} / \mathrm{ml}$. This result indicates that the primary site of action of lipopeptin $A$ is not the inhibition of synthesis of $\beta$-1,3-glucan, major component of cell wall.

Lipopeptin A inhibited chitin synthesis at high concentration (Fig. 6). Concentration required for $50 \%$ inhibition was estimated to be $750 \mu \mathrm{g} / \mathrm{ml}$. This is a much higher value compared to the minimal inhibitory concentration $(150 \mu \mathrm{g} / \mathrm{ml})$ in in vivo testing.

Although details of fungal proteoheteroglycan synthesis is not known, we studied the incorporation of sugars from GDP-mannose and UDP-GlcNAc into proteo-heteroglycan by a particulate enzyme from $P$. oryzae. The enzyme was found to catalyze the incorporation of mannose from GDP-[U- $\left.{ }^{14} \mathrm{C}\right]$ mannose and GlcNAc from UDP- $\left[\mathrm{U}-{ }^{14} \mathrm{C}\right] \mathrm{GlcNAc}$ into proteoheteroglycan. This reaction is dependent on

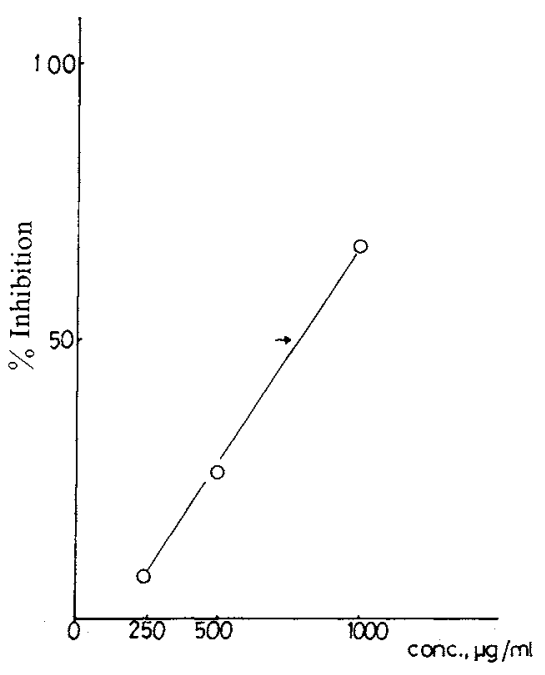

Lipopeptin A

FIG. 6. Effect of Lipopeptin A on Chitin Synthesis. Each reaction mixture contained $0.6 \mathrm{~mm}$ UDP-[U$\left.{ }^{14} \mathrm{C}\right] \mathrm{GlcNAc}$ (Sp. Act. $300 \mu \mathrm{Ci} / \mu \mathrm{mol}$ ), $16.7 \mathrm{~mm}$ Trismaleate- $\mathrm{NaOH}$ buffer $\mathrm{pH} 7.2,2.7 \mathrm{mM} \mathrm{MgCl}_{2}, 0.6 \mathrm{~mm} \beta$ mercaptoethanol, $0.06 \mathrm{mM}$ EDTA, $17 \mathrm{~mm}$ GlcNAc, antibiotic as indicated, and $10 \mu l$ of $P$. oryzae particulate enzyme in a total volume of $60 \mu$ l. Incubation was conducted at $25^{\circ} \mathrm{C}$ for $2 \mathrm{hr}$. The arrow shows the concentration for $50 \%$ inhibition.

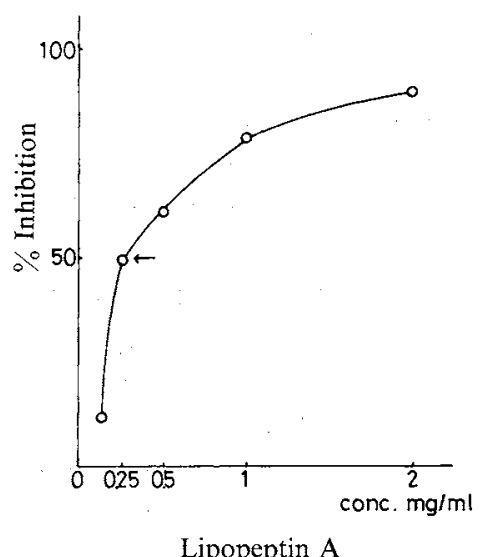

FIG. 7. Effect of Lipopeptin A on the Transfer of Mannose from GDP- $\left[\mathbf{U}-{ }^{14} \mathrm{C}\right]$ Mannose into Proteoheteroglycan.

Each reaction mixture contained $1.4 \times 10^{-3} \mathrm{mM}$ GDP[U- $\left.{ }^{14} \mathrm{C}\right]$ mannose (Sp.Act. $\left.146 \mu \mathrm{Ci} / \mu \mathrm{mol}\right), 20 \mathrm{~mm}$ sodium cacodylate- $\mathrm{HCl}$ buffer $\mathrm{pH} 6.5,10 \mathrm{~mm} \mathrm{MnCl}_{2}, 1 \mathrm{~mm} \beta$ mercaptoethanol, and $10 \mu \mathrm{l}$ of $P$. oryzae particulate enzyme in a total volume of $50 \mu$ l. Incubation was conducted at $25^{\circ} \mathrm{C}$ for $60 \mathrm{~min}$. 


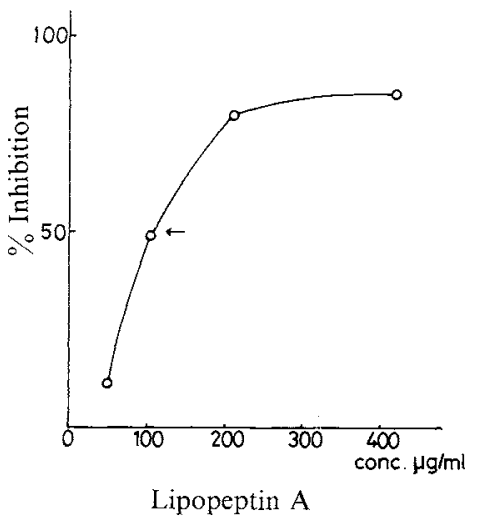

FIG. 8. Effect of Lipopeptin A on the Transfer of GlcNAc from UDP-[U- $\left.{ }^{14} \mathrm{C}\right] \mathrm{GlcNAc}$ into Proteoheteroglycan.

Each reaction mixture contained the same components as shown in Fig. 7 except $6.7 \times 10^{-4} \mathrm{mM}$ UDP-[U$\left.{ }^{14} \mathrm{C}\right] \mathrm{GlcNac}$. Incubation was conducted at $25^{\circ} \mathrm{C}$ for $30 \mathrm{~min}$.

concentration of $\mathrm{Mn}^{++}$(data not shown). As shown in Fig. 7 and Fig. 8, lipopeptin A inhibited the transfer of mannose and GlcNAc and the ID $_{50}$ values were found to be $250 \mu \mathrm{g} / \mathrm{ml}$ and $100 \mu \mathrm{g} / \mathrm{ml}$, respectively.

From these results, we conclude that lipopeptin A inhibits the synthesis of proteoheteroglycan and to lesser extent, chitin synthesis. The primary site of action of this antibiotic may be the inhibition of the transfer of GlcNAc into proteo-heteroglycan. Although the total structure of proteoheteroglycan of $P$. oryzae is not established yet, it may be that it has diacetylchitobiose structure $N$-glycosidically linked to an asparagine residue of protein as seen in yeast mannan. ${ }^{17)}$ If this is the case, the inhibition of transfer of GlcNAc into this moiety by lipopeptin A would also result in the inhibition of transfer of mannose which is linked successively to the diacetylchitobiose.

\section{DISCUSSION}

Lipopeptin A has a long chain fatty acid as seen in other antibiotics which inhibit cell wall synthesis, e.g., tunicamycin ${ }^{18)}$ enduracidin, ${ }^{4}$ (6) amphomycin, ${ }^{3)}$ and moenomycin, ${ }^{19)}$ etc. Lipopeptin A resembles enduracidin in view of the lactone structure, in which the hydroxyl group of threonine participate in the lactone formation. In this paper, we showed that lipopeptin A inhibits peptidoglycan synthesis as the results of inhibition of the formation of GlcNAc-MurNAc-pentapeptide$p$-p-lipid. Lipopeptin A does not inhibit the formation of MurNAc-pentapeptide- $p$ - $p$-lipid. Also it does not inhibit polymerase reaction. In view of the structure-activity relationship, it is interesting that both lipopeptin $A$ and enduracidin inhibit the same site. Enduracidin inhibits peptidoglycan synthesis and the site of action is reported to be the inhibition of the formation of GlcNAc-MurNAc-pentapeptidep-p-lipid. ${ }^{7)}$

Lipopeptin A also caused swelling of mycelia of fungi, as seen in polyoxins, ${ }^{13)}$ selective inhibitors of chitin synthetase. However, lipopeptin A inhibited the incorporation of glucosamine into TCA insoluble fraction of mycelial suspention of $P$. oryzae only slightly. Incorporations of uridine, thymidine, phenylalanine, or sodium acetate in vivo were also not inhibited.

In in vitro experiment, we attempted to see the effect of lipopeptin A on chitin, $\beta$-1,3glucan, and proteo-heteroglycan syntheses with a particulate enzyme from $P$. oryzae. $\beta$ 1,3-Glucan synthesis was inhibited only by $17 \%$ at the concentration of $1 \mathrm{mg} / \mathrm{ml}$ of lipopeptin A but chitin synthesis was inhibited at the high concentration of the antibiotic $\left(\mathrm{ID}_{50} ; 750 \mu \mathrm{g} / \mathrm{ml}\right.$ ). Recently, Nakajima et al. ${ }^{16)}$ in the study of cell wall components of $P$. oryzae, clarified the partial structure of proteoheteroglycan, which has a carbohydrate moiety composed of D-mannose, D-glucose, and Dgalactose in a ratio of $6: 2: 1$. They suggested that proteo-heteroglycan might have two kinds of carbohydrate-protein linkage, namely $N$-glycosidic and $O$-glycosidic. In yeast mannan, ${ }^{17)}$ a heteropolysaccharide moiety is linked via a diacetylchitobiose bridge by an $N$ glycosidic bond to an asparaginyl residue in the protein part and a short mannooligosaccharide is $O$-glycosidically linked to serine 
and/or threonine residues in the protein. Most of mannosyl units in the mannan molecule are transferred from GDP-mannose. However, in some cases, the transfer of mannosyls to mannan does not occur directly but through lipid intermediate, dolichol phosphate mannose. In the biosynthesis of $N$-glycosidically linked mannan, $N$-acetylglucosamine is transferred from UDP-GlcNAc to dolichol phosphate to give dolichol- $p-p$-GicNAc and dolichol- $p-p-(\mathrm{GlcNAc})_{2}$.

Biosynthesis of carbohydrate moiety of proteo-heteroglycan in $P$. oryzae is not known and existence of $N$-glycosidic and $O$-glycosidic linkages in proteo-heteroglycan is only presumptive. In the present study, we showed that lipopeptin $A$ inhibited the transfer of mannose from GDP-mannose into proteo-heteroglycan. Lipopeptin A was also found to inhibit transfer of GlcNAc from UDP-GlcNAc. In our in vitro system, GlcNAc, the primer of chitin synthesis and $\mathrm{Mg}^{++}$ion are absent and the concentration of UDP-GlcNAc is very low compared to the $\mathrm{Km}\left(1.43 \times 10^{-3} \mathrm{M}\right)$ of chitin synthease. ${ }^{20}$ Because chitin synthesis does not occur in this conditions, the transfer of GlcNAc from UDP-GlcNAc may reflect only proteo-heteroglycan synthesis but not chitin. This assumption was supported by the fact that $\mathrm{ID}_{50}$ value for proteo-heteroglycan (100 $\mu \mathrm{g} / \mathrm{ml}$ ) of lipopeptin A was lower than that for chitin synthesis $(750 \mu \mathrm{g} / \mathrm{ml})$.

In conclusion, the swelling of mycelia of fungi caused by lipopeptin A may be due to the inhibition of cell wall synthesis, especially proteo-heteroglycan synthesis and the site of action is suggested to be the transfer of GlcNAc into proteo-heteroglycan.

This may explain failure of significant inhibition of glucosamine incorporation in vivo by lipopeptin A. If the structure of proteoheteroglycan of $P$. oryzae has indeed diacetylchitobiose linked to an asparagine residue of protein as seen in yeast mannan, the chemical content of this $N$-acetylglucosamine should be considerably low, thus the inhibition of incorporation in vivo can hardly be observed.

Recently, Kang et al. ${ }^{21,22)}$ reported that amphomycin inhibits the transfer of mannose from GDP-mannose and GlcNAc from UDPGlcNAc to lipid linked saccharide with enzyme preparations of pig arota. Inhibition of the transfer of GlcNAc is known in tunicamycin, which inhibits the formation of dolichol-p-p-GlcNAc. ${ }^{23)}$ Lipopeptin $A$ has a long chain fatty acid as seen in these two antibiotics; thus, the inhibition of proteoheteroglycan synthesis by this antibiotic may suggest the presence of lipid intermediate in cell wall glycan synthesis in $P$. oryzae.

Acknowledgment. We are grateful to Dr. T. Nakajima of Tohoku University for his valuable discussion and helpful advice. We also thank Mrs. R. Nishii for her technical assistance.

\section{REFERENCES}

1) K. Tsuda, T. Kihara, M. Nishii, G. Nakamura, K. Isono and S. Suzuki, J. Antibiot., 33, 247 (1980).

2) M. Nishii, T. Kihara, K. Isono, T. Higashijima, T. Miyazawa, S. K. Sethi and J. A. McCloskey, Tetrahedron Lett., 1980, 4627.

3) M. Bodanszky, G. F. Sigler and A. Bodanszky, $J$. Am. Chem. Soc., 95, 2352 (1973).

4) E. Higashide, K. Hatano, M. Shibata and K. Nakazawa, J. Antibiot., 21, 12 I (1968).

5) M. Asai, M. Muroi, N. Sugita, H. Kawashima, K. Mizuno and A. Miyake, J. Antibiot., 21, 138 (1968).

6) H. Iwasaki, S. Horii, M. Asai, K. Mizuno, J. Ueyanagi and A. Miyake, Chem. Pharm. Bull., 21, 1184 (1973).

7) H. Tanaka, Oiwa, S. Matsukura and S. R. Ōmura, Biochem. Biophys. Res. Commun., 86, 902 (1979).

8) M. Matsuhashi, I. Ohara and Y. Yoshiyama, Agric. Biol. Chem., 33, 134 (1969).

9) K. Izaki, M. Matsuhashi and J. L. Strominger, $J$. Biol. Chem., 243, 3180 (1968).

10) J. S. Anderson, M. Matsuhashi, M. A. Haskin and J. L. Strominger, J. Biol. Chem., 242, 3180 (1967).

11) M. Hori, K. Kakiki and T. Misato, Agric. Biol. Chem., 38, 691 (1974).

12) T. Kusano and $\mathrm{K}$. Isono, manuscript in preparation.

13) K. Isono, K. Asahi and S. Suzuki, J. Am. Chem. Soc., 91, 7490 (1969).

14) T. Nakajima, K. Tamari, K. Matsuda, H. Tanaka and N. Ogasawara, J. Am. Chem. Soc., 34, 553 (1970)

15) T. Nakajima, K. Tamari, K. Matsuda, H. Tanaka and N. Ogasawara, J. Am. Chem. Soc., 36, 11 (1972).

16) T. Nakajima, K. Tamari and K. Matsuda, $J$. Biochem., 82, 1647, 1657 (1977).

17) V. Farkas, Microbiol. Rev., 43, 117 (1979). 
18) T. Ito, A. Takatsuki, K. Kawamura, K. Sato and G. Tamura, Agric. Biol. Chem., 44, 695 (1980).

19) G. Huber, U. Schacht, H. L. Weidenmüller, J. Schmidt-Thomé, J. Duphone and R. Tschesche, Antimicrob. Agents Chemoth., 1965, 737 (1966).

20) A. Endo, K. Kakiki and T. Misato, J. Bact., 104, 189 (1970).
21) M. S. Kang, J. P. Spencer and A. D. Elbein, Biochem. Biophys. Res. Commun., 82, 568 (1978).

22) M. S. Kang, J. P. Spencer and A. D. Elbein, J. Biol. Chem., 253, 8860 (1978).

23) L. Lehle and W. Tanner, FEBS Letters, 71, 167 (1976). 